\title{
Environmental Variables and Chemistry Students' Achievement in Secondary Schools in Akwa Ibom State of Nigeria
}

\author{
Udoh, Akpan Oko \\ Department of Educational Foundations, Guidance and Counselling, \\ University of Uyo, Uyo, Akwa Ibom State, Nigeria \\ E-mail: akapnokoudoh@yahoo.com, Tel: +2348035467229
}

\author{
Doi:10.5901/jesr.2013.v4n3p275
}

\begin{abstract}
The study aimed at assessing how 13 environmental variables taken together predict students' achievement in Chemistry as well as their relative contribution to the prediction. Two research questions were raised and stratified random sampling technique was used to select 94 Chemistry teachers and 600 of their Chemistry students for the study. Environmental variable Questionnaire 1 and 11 and Chemistry Achievement Test (CAT) were used for data collection and analysed using multiple regression. The results showed that the 13 variables taken together had significant contribution to students' achievement in Chemistry and accounted for $77.34 \%$ of the variation in students' achievement in Chemistry. It was recommended that stakeholders in provision of Chemistry education at the secondary school level should consider the eight variables that contributed significantly to achievement seriously during planning and executing Chemistry education programmes for optimum achievement of students.
\end{abstract}

\section{Background to the Study}

Chemistry is a very useful subject especially when considering its implementations to well being of the Nigerians.

Umoinyang and Okpala (2001) stated three societal needs which could be accomplished through the knowledge of chemistry. These are the needs for physical survival, living a satisfactory economics life ad raising the level of our sociocultural life. The knowledge of chemistry has enable us to produce good water, food and health care resources, varying materials for construction of industries, roads, automobile and home appliances in addition to solving problems resulting from human interaction with environment.

Even though the knowledge of chemistry to the society is very important, students' achievement in chemistry as measured by their scores in senior secondary certificate examination is very poor. Senior secondary certificate examinations are taken at the end of senior secondary school education.

Asim, Bassey and Essien (2005) reported that the percentages of students that passed chemistry at credit level and above in the senior secondary school certificate in 1999, 2000, 2001 and 2002 were 31.38\%, 36.25\% and 25.38\% respectively. These values are considered very low because these are the percentages of applicant who were qualified for university admission in science related programmes other things be equal.

Factors that influence students' achievement at the senior secondary school are multivariate. These factors include - teachers' qualification, quantity of instruction and attitude (Caleb, 2001: Buker \& Ibi, 2003): social environment factor (Udoh, 1998); socio-psychological factors (Umoinyang \& Okpala, 2001), teaching learning resources, teachers characteristics, students characteristics, school-community relation, school characteristics, student, community, school and teacher characteristics, classroom context, teacher perceptions, quantity of instruction, teacher -student relationship, assessing and evaluating students, managing students, student perceptions and students participation in learning (Anderson, 1987). The review showed that most studies done in Nigeria in this area concentrated on the relationship existing between very few variables. Additionally, they failed to show the strength of the relationship and those that did show the strength of relationship between the variables only studied very few variables. But Udoh (2005) maintained that educational phenomena have educational, psychological and sociological connotations. It is therefore clear from this background that students' achievement cannot be accounted for by one, two or three variables but a number of them. Furthermore, no study in Nigeria has sought the contribution of up to 13 variables to achievement in chemistry at the secondary school level.

This study therefore sought to explain students' achievement in chemistry using 13 environmental variables namely:- use of teaching/learning materials, orientating students, quantity of instruction, classroom context, teachers', 
perception, home characteristics, school location, school characteristic, teachers' characteristics, examining students, teachers' autonomy, managing students and students' perception.

Two Research questions were raised. They are:-

1. How do the thirteen variables earlier listed taken together predict students' achievement in chemistry?

2. What is the relative contribution of the variables to the prediction?

\section{Method}

This is an expost-facto study, using correlational research design.

The study was carried out in Akwa Ibom State of Nigeria. Two categories of target

population were involved in the study;- (i) chemistry students and (ii) chemistry teachers. The students' population comprised all the 24,102 senior secondary III chemistry students who registered for May/June senior secondary certificate examinations in 2010/2011 school year, and their 241 chemistry teachers. Stratified random sampling technique was used in selecting 94 schools, 40 urban, 24 sub-urban and 30 rural schools, for the study. One teacher, who taught senior secondary III chemistry from each of the 94 schools, participated in the study. The same sampling method was used in selected $40 \%$ of chemistry students taught by these teachers. However, 600 out of 612 students had complete data and participated in the study.

Three instrument were used in the study

i. Environmental Variable Questionnaire 1 (EVQ1) responded to by teachers.

ii. $\quad$ Environmental Variable Questionnaire 11 (EVQ11) responded to by students and teachers.

iii. Chemistry Achievement Test (CAT). to be taken by students

All the instruments were developed by the researcher. EVQ1 had 11 sections:- chemistry teachers' characteristics, school location, school characteristics, use of teaching/learning materials, teachers autonomy, quantity of instruction, orientating students, classroom contents, examining students, managing students and chemistry teachers' perception of their students. EVQ 11 had two sections:- student's perception and their home background. The reliability of variables in LEQ1 and 11 are shown in Table 1.

Table 1: Reliability of each section of the EVQ 1 and 11

\begin{tabular}{|c|l|c|}
\hline S/N & \multicolumn{1}{|c|}{ Sub-section of EVQ 1\&11 } & Cronbach Alpha \\
\hline 1. & Chemistry teachers' characteristics & .84 \\
2. & School Location & .77 \\
3. & School characteristics & .75 \\
4. & Use of teaching/learning materials & .74 \\
5. & Teachers' autonomy & .69 \\
6. & Quantity of instruction & .85 \\
7. & Orienting students & .78 \\
8. & Classroom context & .75 \\
9. & Examining students & .78 \\
10. & Managing students & .68 \\
11. & Chemistry teachers' perception & .81 \\
12. & Students' perception & .76 \\
13. & Students home characteristics & .81 \\
\hline
\end{tabular}

Table 1 showed that the reliability of quantity of instruction and managing students were highest (.85 Cronbach alpha) and lowest (.68 of Cronbach alpha) respectively.

The reliability of Chemistry Achievement Test (CAT) was .81 and .97 as concurrent validity.

\section{Results}

Data were analysed using multiple regression analysis using SPSS package.

Each research question was separately treated. 


\section{Research Question One}

How do the 13 variable taken together predict students' achievement in chemistry:

Summary of regression analysis on the data are shown in Table 2.

Table 2: Summary of regression analysis on sample data

Multiple $\mathrm{R}=0.8746$

$R$ square $\left(R^{2}\right)=0.7734$

\begin{tabular}{|c|c|c|c|c|}
\hline Source & $\mathrm{df}$ & SS & MS & $F_{\text {cal }}$ \\
\hline \multirow[t]{3}{*}{ Regression } & 13 & 756.0314 & 58.3916 & \\
\hline & & & & 20.60 \\
\hline & 80 & 226.4023 & 2.8331 & \\
\hline Total & 93 & 982.4337 & 982.437 & \\
\hline
\end{tabular}

The value of regression coefficient square $\left(\mathrm{R}^{2}\right)$ of 0.7734 indicate that $77.34 \%$ of variation in students achievement in chemistry was accounted for (predicted) by the 13 variable since the F-ratio of 20.60 is significant at df of 13,20 and 0.5 level of significant $\left(F_{\text {crital }}=2.28\right)$.

\section{Research Question Two}

What is the relative contribution of the variables to the prediction?

The relative contribution of the 13 variable to achievement in chemistry is shown in Table 3.

Table 3: Reliability of each section of the EVQ1 \&11

\begin{tabular}{|c|l|c|c|}
\hline S/N & \multicolumn{1}{|c|}{ Sub-section of LEQ 1\&11 } & Regression coefficient B & Remarks \\
\hline 1. & Use of teaching/learning materials & 0.085 & $\mathrm{X}$ \\
2. & Orientating students & 0.004 & $\mathrm{NS}$ \\
3. & Quantity of instruction & 0.004 & $\mathrm{NS}$ \\
4. & Classroom context & 0.035 & $\mathrm{NS}$ \\
5. & Chemistry teachers' perception & 0.208 & $\mathrm{X}$ \\
6. & Students home characteristics & 0.080 & $\mathrm{X}$ \\
7. & School location & 0.090 & $\mathrm{X}$ \\
8. & School characteristics & 0.003 & $\mathrm{NS}$ \\
9. & Chemistry teachers' characteristics & 0.051 & $\mathrm{X}$ \\
10. & Examining students & 0.50 & $\mathrm{X}$ \\
11. & Teachers' autonomy & 0.008 & $\mathrm{NS}$ \\
12. & Managing students & 0.68 & $\mathrm{X}$ \\
13. & Students' perception & 0.306 & $\mathrm{X}$ \\
\hline
\end{tabular}

$X=$ Significant at $\mathrm{p}<.05$

NS $=$ Not significant at $p>05$

Use of teaching/learning materials, chemistry teachers perception, students home characteristics, school location, chemistry teachers characteristics, examining students, managing students and students perception contributed significantly $(P<.05)$ to chemistry students achievement while orientating students, quantity of instruction, classroom context, school characteristics and teachers autonomy did not.

\section{Discussion}

The results of regressing achievement on the 13 variables reaffirmed the existing assertion that: environmental variables could have potential influence on achievement. The results were support by Balogun (1993), Toit (1996), Umoinyang \& 
Okpala (2001), Caleb (2001), UNSECO (2002) and Ojierinde (2005).

The highest contribution of students' perception $(B=0.306)$ to achievement in chemistry is consistent with findings of Bakare (1986), Anderson (1987), Busari (1991) and Caleb (2001) who maintained that students' perception of science correlate positively with achievement. They added that; the way students perceive themselves influence their goals and attitude toward processing and in fact relative effort put-in in order to accomplish their aims. If a student perceives himself as a high achiever, he is likely to work harder to ensure such accomplishment. Teachers' perception $(B=0.208)$ also contribution significantly to chemistry students' achievement. This finding supports' that of Anderson (1987). The way teachers perceive their students' academic ability influence their teaching and interaction with the students. Teachers should ensure that their perception is right.

School location $(B=0.904)$ significantly contributed to chemistry students' achievement. This finding was consistent with the result of many studies, such as Willeny (1981), Ezeife (1990), and Umoinyang \& Okpala (2001). The finding was however at variance with those of Jegde (1984) and Odumusi (1984), use of teaching/learning materials ( $B=$ 0.085) also contributed significantly to chemistry students' achievement. This finding was supported by that of Obioma (1991) who found that students in completely materials-based environment scored significantly higher than their counterparts in a traditional classroom that had the chalkboard.

Home characteristics $(B=0.080)$ also contributed significantly to chemistry students' achievement. The finding was supported by many studies like Bakare (1986), Ajaia (1986) and Alonge (1989). Managing students (B = 0.068) significantly contributed to chemistry students' achievement. The finding was supported by Ojerinde (2005). Teachers' characteristics $(B=0.051)$ also contributed significantly to chemistry students' achievement. This finding was in consonant with the results of many studies including those of Anderson (1987), Balogun (1993). However, other studies showed no significant relationship between teachers' characteristics and achievement. Such studies include those of Jedege (1984), and Igwe (1990).

In this study, teachers' characteristics contributed significantly to achievement. This finding is supported by Bukar and Ibi (2003). Examining students $(B=0.050)$ also contributed significantly to chemistry students' achievement. This finding was supported by Johnston (1991) who maintained that throughout the world, assessment and examination systems have enormous influence on what is learned and examined.

It was observed that orientating students $(B=0.004)$ made no significant contribution to chemistry students' achievement. It appears chemistry teachers do not adequately get their students' prepared and ready for a new lesson. Udoh (1998) opined that in class, students differ in physical appearance, intelligent, sociability, temperament, social personal background hence orienting strategies which succeed with bright may not be useful to average or less bright ones since chemistry teachers have to bring a class of varying academic ability into a stage of readiness before the commencement of lessons.

Quantity of Instruction $(B=0.004)$ also did not contribute significantly to achievement. This finding was not surprising when considering the result of previous findings. For instance, Fredrick and Walbery (1980) found that the actual time spent on learning, homework and assignment did not contribute to students' achievement. School characteristics $(B=0.03)$ did not contribute significantly to chemistry student's achievement. Studies on school characteristics showed that what is currently happening in school could result in no significant relationship on students' achievement (Obimas, 1991).

Classroom context $(B=0.035)$ did not also contribute to chemistry students' achievement. Ordinarily, one would expect variable of the classroom context to contribute significantly to students' achievement, which this study has shown to be contrary. Anderson (1987) supported this result by observing that teachers' classroom activities tended to exert no influence on achievement.

\section{Conclusion}

Stakeholders (like Federal and State Ministry of Education and their agencies) in the provision of education at this level should consider the eight variables that contribute significantly to achievement during planning and execution of chemistry education progragmmes if they have to bolster students' performance in chemistry.

\section{References}

Ajala, J. A. (1986) The School problems that lead to failure of Nigerian Public Examinations. Proceedings of the National conference on Mass failure in Public Examination. Ibadan. 
Alorge, M. F. \& Ojerinde, A. (1986, April). Cheating tendency and differential performance of secondary school students in Mathematics achievement tests. Journal of Science Teachers Association of Nigeria, 25(2), 96-102.

Anderson, L. W. (1987). Summary, conclusion and implication of IEA Report. Comparative Education Review, 31 (1), 98-101.

Asim, A. E. Bassey, U. U \& Esseien, M. I. (2005), Trend analysis of West

African Senior Certificate Examination results in Science, Technology and mathematics (STM); Implications for learning in Nigeria Secondary Schools. 31st proceedings of International Association for Education Assessment. Abuja.

Awokaya, S. O. (1976). Strategies for the reform of education to meet national development. Seminar paper of Education and manpower needs, Jos: Government printers.

Balogun, L. (1993, March 21). Teaching profession, a curse or blessing. Daily Times of Nigeria, p8.

Bakare C. G. (1986). Mass failure in public examination. Some psychological Perspective. Producers of National Conference on Mass Failure in public Examination. Ibadan.

Bukar, K \& Ibi M. B. A. (2003). Relationship between teacher quantity, qualification and students academic achievement in selected practical construction course on technical colleges in Yola. The Nigerian Teacher Today, 2 (1), 76-85.

Busari P. (1991, April). Sustaining student interest in science: influence of cognitive and teacher variables. Journal of Science Teaches Association of Nigeria. 21 (1) 30-37.

Caleb, B. (2001, September). Some psychosocial correlates of the choice of academic subjects in senior secondary schools in Zaria Metropolis. West African Journal of Education Research, 4(2) 95104.

Ezeife, A. N. (1990). Sex and environment as factors in physics achievement. International Journal of Education Research, 4.6270.

Fredicks, W. C, \& Walbery, H. F. (1980). Learning as a function of time. Journal of Education Psychology, 84 (73), 36-47.

Igwe, D. O. (1990, April). Science teachers' qualification and students Performance in secondary school in Kano State. Journal of Science Teachers Association of Nigeria, 26 (2), 43-50.

Jegede, B. A. (1984, April). Non-cognitive correlates of secondary school students achievement in physics. Journal of Science Teachers Association of Nigeria, 61 (31), 46-53.

Johnstone, A. (1991). How can knowledge and understanding of Chemistry be effectively assessed? 11th international Conference of Chemistry Education. England: Book of Abstract.

Ndem, U.; Udoh, A. O. \& Joseph, E. (2005). Foundations of Educational Research. Ikot Ekpene: Paton Publishers.

Obioma, E. O. (1991 April). A study of the attitude of some Nigerians science students toward science and science teaching. Journal of Science Teachers Association of Nigeria, 22 (2). 27-33.

Ojerined, D. (2005), Equating school assessment results with certificate Examinations in Nigeria. 31st proceeding of International Association for Education Assessment, Abuja.

Toit, C. J. (1991). Factors which affect the attitude of school and University students toward chemistry. England: Book of Abstracts.

Universal Basic Education, (2002). Training manual for Nigeria primary school inspectors and supervisors. Abuja: UBE.

Udoh. A. O. (1998). Some correlates of students' achievement in IntegratedScience University of Ibadan. Seminar paper.

Umoinyang, I. E. \& Okpala, P. (2001, June). Socio-psychological factors, knowledge and understanding of mathematics achievement at cognitive level of thinking. Evaluation Research, 1 (1), 55-62. 
